\title{
Entrepreneurial Barriers Faced by Disabled in India
}

\author{
Ahmar Uddin Mohammed ${ }^{1} \&$ Syed Ahsan Jamil ${ }^{1}$ \\ ${ }^{1}$ Department of Accounting and Finance, College of Commerce and Business Administration, Dhofar University, \\ Oman \\ Correspondence: Ahmar Uddin Mohammed, Department of Accounting and Finance, College of Commerce and \\ Business Administration, Dhofar University, Oman. E-mail: ahmar@du.edu.om
}

\author{
Received: February 4, 2015 Accepted: March 14, 2015 Online Published: August 18, 2015 \\ doi:10.5539/ass.v11n24p72 URL: http://dx.doi.org/10.5539/ass.v11n24p72
}

\begin{abstract}
India has witnessed high economic growth rates in the past two decades and there has been a remarkable increase in the per capita income. But unfortunately many sections of the Indian population still remain economically deprived. Disabled persons though constitute a small part of the Indian population but their relative numbers are growing. Disabled lag behind in terms of education and employment which results in poverty. For equitable distribution of wealth and prosperity among all sections of population inclusive growth is necessary. The challenge is therefore not only to achieve higher economic growth rates but also to focus on economic inclusion so that all sections of the society are able to take advantage of opportunities. Promoting entrepreneurship among the disabled is a way to achieve faster and better economic integration. This paper highlights the barriers faced by entrepreneurs with disabilities. Also the paper tries to find out if these barriers are different than those faced by other entrepreneurs. Finally this paper highlights what steps can be taken to prevail over the various types of barriers being faced by disabled entrepreneurs.
\end{abstract}

Keywords: entrepreneurship, disabilities, inclusive growth, barriers, economic integration

\section{Introduction}

As a result of the thrust on economic development the Indian per capita income has increased almost three times from USD 318 in 2002-03 to USD 889 in 2010-11. India stands at third position worldwide in terms of purchasing power parity. But despite the extraordinary increase in rate of economic growth; there is stagnation in key social indicators and millions of the country's underprivileged are still deprived of basic amenities. Majority of Indians (77 percent), live on less than half a dollar a day (World Bank, 2013). Aware of such disparities, the government of India is now giving more consideration towards inclusive growth (in its Eleventh and Twelfth Five Year Plans). The focus is to take the levels of growth to all section of the society.

Disability can be stated as some kind of impairment which results in sustained restriction in daily activities. As per World Health Organisation (2011), disability is growing worldwide due to the rise in ageing population and increase in the incidence of chronic health conditions. In India, during the last decade 2001- 2011 the disabled population has increased from 21.9 million to 26.8 million, which is an increase of 22.4 percent (Census of India, 2011).

Table 1. Growth of Disabled Population in India 2001- 2011 (By Gender and Region)

\begin{tabular}{lcccccc}
\hline & \multicolumn{3}{c}{ Absolute Growth (in millions) } & \multicolumn{3}{c}{ Percentage Growth } \\
\hline Region & Persons & Males & Females & Persons & Males & Females \\
Total & 4.90 & 2.3 & 2.52 & 22.4 & 18.9 & 27.1 \\
Rural & 2.24 & 0.99 & 1.24 & 13.7 & 10.6 & 17.8 \\
Urban & 2.66 & 1.38 & 1.27 & 48.2 & 43.3 & 55.0 \\
\hline
\end{tabular}

Source: Compiled from Census of India, 2011.

Disability is both the cause and the result of poverty. Disabled person lags behind in terms of education and 
finding suitable employment which results in poverty. Also the living conditions of poor persons can result in some sort of disability. Disabled persons may be of different types and have diverse abilities and interests but all of them experience one common problem which is their economic exclusion due to disability. The adverse impact of disabilities on education and employment has been highlighted by various researchers (Jones, 2008; Meager \& Higgins, 2011) and encouraging entrepreneurship among the disabled to achieve faster and better economic integration has been suggested (Arnold \& Seekins, 2002).

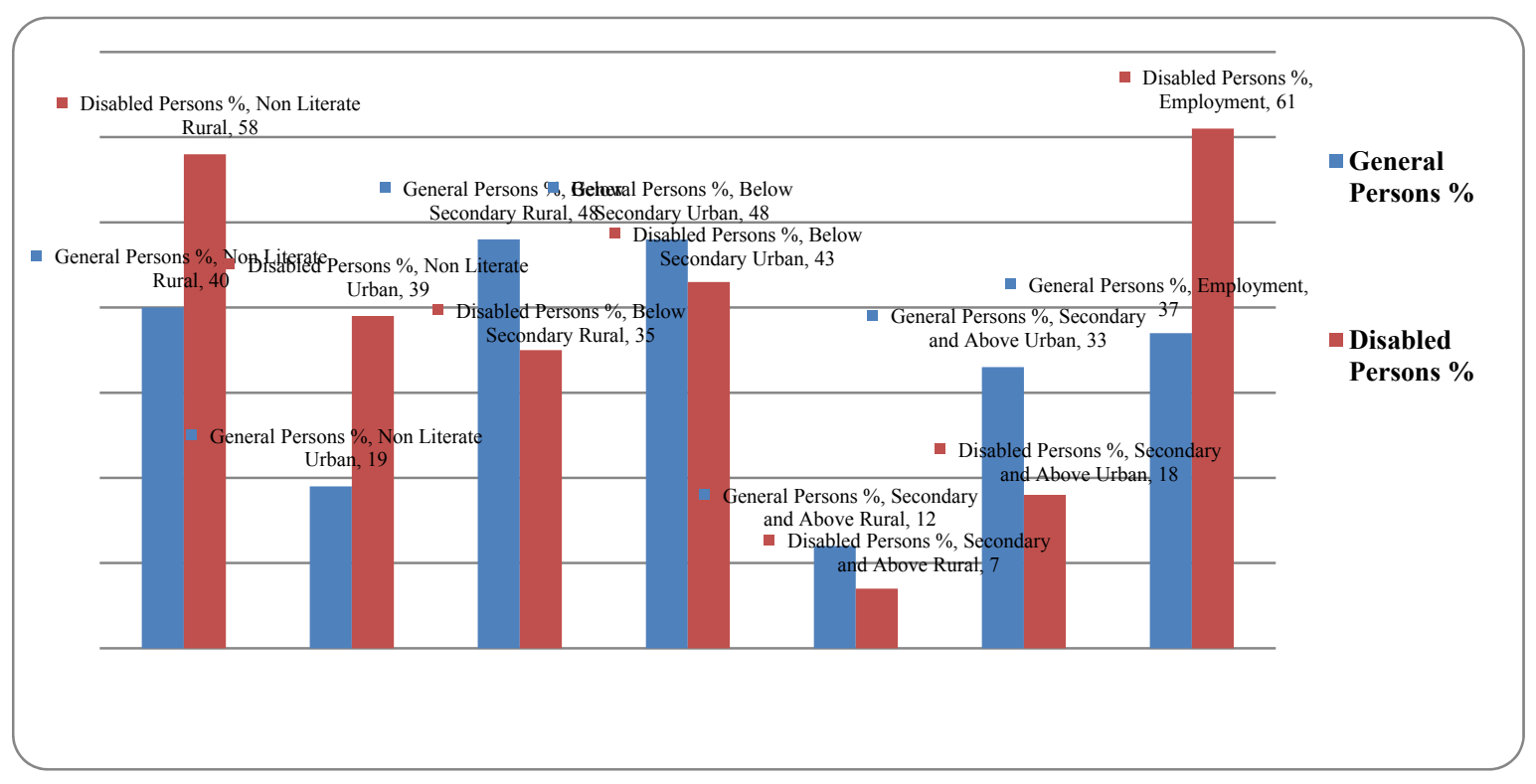

Source: Compiled from Census of India, 2011.

Figure 1. Educational and Employment Status of Disabled Persons

\section{Literature Review}

In many parts of the world such as in Europe and America the entrepreneurship rates are higher among disabled people as compared to others (Boylan \& Burchardt, 2002; Meager \& Higgins, 2011). Researchers have attributed various reasons to the higher rates of Entrepreneurship such it can provide flexibility in terms of working hours and location enabling better adjustment between disabilities and work (Prescott-Clarke, 1990; Callahan et al., 2002; Doyel, 2002; Pagan, 2009; Jones \& Latreille, 2011; Meager \& Higgins, 2011). Other researchers emphasize factors such as a lack of alternative employment opportunities and employer discrimination for having a higher rate of entrepreneurship among the disabled (Blanck et al., 2000; Boylan \& Burchardt, 2002; Hagner \& Davis, 2002; EMDA, 2009; Foster, 2010). The stereotype associated with the disabled also negatively influences the perception of employers and thus reduce their opportunities for employment (Davidson, 2011).

\subsection{Barriers to Entrepreneurship among the Disabled}

In addition to the general barriers disabled people also likely to face specific barriers in entrepreneurship. Many of these barriers are deep-rooted social-structural constraints imposing severe limits on the disabled. These barriers can be summarized as:

\subsubsection{Market Prejudices}

Entrepreneurs experience market prejudices which may be due to their gender, age, religion and caste. In addition to the above prejudices there is also a reduced demand for goods and services produced by disabled persons. This can reduce the rewards to entrepreneurship to the disabled entrepreneur as compared to other entrepreneur (Boylan \& Burchardt, 2002; Jones \& Latreille, 2011).

\subsubsection{Business Contacts}

Entrepreneurs rely on their formal and informal contacts for social influence and experience. Disabled persons may have again have more difficulties in establishing and maintain business contacts (Hoang \& Antoncic, 2003). 


\subsubsection{Access to Finance}

Entrepreneurs often experience difficulties financing new start-ups due to limited personal financial resources (savings, home ownership). Finance is an important for the establishment and growth of entrepreneurial businesses (Berger \& Udell, 2006). Disabled entrepreneurs may face more constraints in collecting funds for business due to reasons such as their stereotypes, poor education, lower employment rates, lack of accessible information on sources of grants and discrimination on the part of banks and other financing agencies (Boylan \& Burchardt, 2002; Foster, 2010).

\subsubsection{Experience}

As compared to other entrepreneurs, due to the constraints of education and mobility disabled people often lack management, legal and financial expertise for entrepreneurship. This limits their opportunity to start and run successful businesses (Enabled4Enterprise, 2008).

\subsubsection{Role Models}

The career choice and future course of actions of an entrepreneur are influenced by others. If the person is of the same social group then the chances of being influenced increases. The lack of role models for the disabled entrepreneurs also acts as an additional barrier (Kirkwood, 2009).

\subsubsection{Self - Belief}

An entrepreneur's self-belief helps in identifying and developing the business opportunity. Persons with disabilities often experience exclusion and rejection. The accrual of such repeated depressing experiences creates incapacities like the lack of self-belief. Disabled entrepreneurs therefore often lack the self-belief that they can start and operate businesses successfully. Also encouragement from formal as well as informal sources helps in creating self-belief and the courage to bear the stigma associated with business failure. Often lack of such support discourages disabled entrepreneurs (Rizzo, 2002; EMDA, 2009; Foster, 2010).

\subsubsection{Government Support}

Government support is any course of action which aims at improving the conditions of Entrepreneurship. Government support as it relates to entrepreneurship is targeted at encouraging entrepreneurship by making a favorable environment for the entrepreneurs. Favorable environment can in terms of policies related to infrastructure, regulations, legal framework, financing and taxation. The policies should be perceived to be supportive by the entrepreneur (Kitching, 2014).

\section{Methodology}

\subsection{Sources of Data}

The disabled entrepreneurs were selected from the list of beneficiaries of National Handicapped Finance Development Corporation (NHFDC), India. Data for other entrepreneurs was collected form the Indian Industry Association. A sample size of 150 disabled and 150 other entrepreneurs was selected through systematic random sampling. The method of questionnaire development was based on the literature review and interview with experts. The questionnaire was then tested on a select group of disabled and normal entrepreneurs. Based on the feedback of pre testing some modifications was done. For this study a structured, undisguised questionnaire was used. Each entrepreneur was asked to rate on a scale from 1 (unimportant) to 5 (very important) the severity of several specific barriers.

\subsection{Objectives of the Research}

The purpose of this study was to find

a) What barriers do people with disabilities face when starting a business?

b) As compared to other entrepreneurs do the disabled entrepreneurs perceive more difficulties in the various barriers to entrepreneurship?

\subsection{Statistical Test}

Multinomial logit regression was used for analyzing the responses from the disabled and other entrepreneurs. In the Multinomial logit regressions, we focus on finding the probability of an entrepreneur facing problem in entrepreneurship due to a particular barrier. The principle of multinomial logistic regression is based on the probability of membership of each category of the dependent variable. So, in our five category example, the focus is on what the probability of having a particular constraint as being unimportant and important for the disabled and other entrepreneurs. 
The way multinomial logistic regression compares the probability of a variable being in each of n- 1 categories compared to a reference category. In a way we can say that we are fitting n-1 separate binary logistic models, where we compare category 1 to the reference category, then category 2 to the reference category and so on. The formula for multinomial logistic regression is where $\operatorname{Pr}\left(y_{i}=j\right)$ is the probability of belonging to group $j, x_{i}$ is a vector of explanatory variables and $\beta_{\mathrm{j}}$ are the coefficients, which are estimated using maximum likelihood estimation.

$$
\operatorname{Pr}\left(y_{i}=j\right)=\frac{\exp \left(x_{i} \beta_{j}\right)}{\sum_{j}^{J} \exp \left(x_{i} \beta_{j}\right)}
$$

Table 2. Results of multinomial regression

\begin{tabular}{|c|c|c|c|c|c|}
\hline Barriers & & B & S.E & Sig & $\operatorname{Exp}(B)$ \\
\hline \multirow{2}{*}{ Market prejudices } & Intercept & 0.847 & 0.178 & 0.000 & \\
\hline & Entrepreneur & 0.049 & 0.259 & 0.850 & 1.050 \\
\hline \multirow{2}{*}{ Business contacts } & Intercept & 0.847 & 0.178 & 0.000 & \\
\hline & Entrepreneur & 0.373 & 0.271 & 0.169 & 1.452 \\
\hline \multirow{2}{*}{ Access to finance } & Intercept & 0.027 & 0.163 & 0.870 & \\
\hline & Entrepreneur & 0.654 & 0.256 & $0.011 *$ & 1.922 \\
\hline \multirow{2}{*}{ Experience } & Intercept & 0.816 & 0.177 & 0.000 & \\
\hline & Entrepreneur & 1.363 & 0.352 & $0.000 * *$ & 1.707 \\
\hline \multirow{2}{*}{ Role models } & Intercept & 0.547 & 0.169 & 0.001 & \\
\hline & Entrepreneur & 0.396 & 0.257 & 0.124 & 1.486 \\
\hline \multirow{2}{*}{ Self - belief } & Intercept & 0.134 & 0.164 & 0.415 & \\
\hline & Entrepreneur & 1.103 & 0.273 & $0.000^{* *}$ & 2.014 \\
\hline \multirow{2}{*}{$\begin{array}{c}\text { Government } \\
\text { Support }\end{array}$} & Intercept & 0.778 & 0.207 & 0.000 & \\
\hline & Entrepreneur & 0.599 & 0.299 & $0.045^{*}$ & 1.821 \\
\hline Significant at 0.05 & Percent Level & & & & \\
\hline$* * \quad$ Significant at 0.01 & Percent Level & & & & \\
\hline
\end{tabular}

\section{Findings}

The findings are shown in table No.2. We find that statistically significant relationship exists for four barriers to entrepreneurship. The barrier where the disabled face more problem as compared to other entrepreneurs are access to finance, experience, self - belief and Government Support.

1. A disabled entrepreneur is 92.2 percent more likely to face barrier due to lack of access to finance as compared to other entrepreneur.

2. A disabled entrepreneur is 70.7 percent more likely to face barrier due to Lack of experience as compared to other entrepreneur.

3. A disabled entrepreneur is 100 percent more likely to face barrier due to Lack of self-belief as compared to other entrepreneur.

4. A disabled entrepreneur is 82.2 percent more likely to face barrier due to Lack of government support as compared to other entrepreneur.

\section{Conclusions and Suggestions}

This study analyzed the response from disabled entrepreneurs and other entrepreneurs as related to their perceptions of the barriers faced by them in entrepreneurship. It was found that disabled entrepreneurs are more 
likely to face barriers in access to finance, experience, self-belief and government support. The following can be done to overcome the barriers faced by disabled entrepreneurs.

\section{Financial Support}

Financial support for the disabled can be in form of financial assistance, loans, subsidised loans and tax exemption. Disabled entrepreneurs need to be informed about the various sources of funds. Disabled people operate on a more flexible basis but financial institutional have a structured working pattern in terms of office time and days. Also there can be discrimination due to disability. Thus there is need to provide more, flexible working hours and sensitize the funding agencies towards the needs of disabled entrepreneurs (Bernard et al., 2006; Greve, 2009; Huang et al., 2009).

\section{Lack of Experience}

The disabled face difficulty in accessing education and employment and consequently, do not get opportunity to develop the desirable entrepreneurial skills. Supporting the acquisition of entrepreneurship skills can help overcome this lack of experience. The goal of entrepreneurship training for people with a disability is similar to the mainstream population. Training of persons with disabilities on the aspects of business such as identifying business opportunity, writing a business plan, developing a product/service, dealing with customers, financial management and employing staff will increase their chances of success.

\section{Lack of Self - Belief}

Awareness training for the disabled can be used to take care of the barriers to entrepreneurship arising from lack of self confidence among disabled entrepreneurs. Entrepreneurship awareness measure refers to the programmes endeavouring to increase knowledge of entrepreneurship as a career option for the disabled. The institutions related to regulating, government departments, banks and other institutions with which the disabled entrepreneur interacts should be responsive. This will result in bridging the gaps with the disabled entrepreneurs. Also a focused confidence building aimed at start ups can address the barrier of lack of confidence faced by disabled entrepreneurs.

\section{Government Support}

The Indian government acknowledges that disabled entrepreneurs need to be encouraged and assisted in entrepreneurship. In the year 1997, under the Ministry of Social Justice and Empowerment the National Handicapped Finance and Development Corporation (NHDC) was set up to promote economic and development activities undertaken by Persons with Disabilities. The Corporation assists the disabled entrepreneurs by providing loans for entrepreneurship and other economic ventures.

Most of the government schemes and policies are generalised to support all types of disabled entrepreneurs. There is a need to understand that generalisation cannot work as there are differences in disabilities such as the type, severity, time period and time of onset of disability. Earlier studies on entrepreneurship for the disabled suggest that concentrated, customized, one-to-one, or small group assistance, may produce the most successful outcomes rather than the generalised government policy support (Arnold \& Ipsen, 2005; Enabled4Enterprise 2009; EMDA, 2009; Dotson et al., 2013).Also government can play a significant role in supporting the development and use assistive technology to ensure continual improvement of entrepreneurs with disabilities. Assistive technology are becoming more sophisticated, increasingly portable, less expensive and easier to use, and as result, hold greater potential for improving the inclusion of people with disabilities in economic activities such as entrepreneurship (Angelocci et al., 2008).

\section{References}

Angelocci, R., Lacho, K. J., Lacho, K. D., \& Galle, W. (2008). Entrepreneurs with Disabilities: The Role of Assistive Technology, Current Status and Future Outlook. Proceedings of the Academy of Entrepreneurship, 14, 1. Tunic.

Arnold, N., \& Ipsen, C. (2005). Self-Employment Policies: Changes through the Decade. Journal of Disability Policy Studies, 16(2), 115-122. http://dx.doi.org/10.1177/10442073050160020201.

Arnold, N., \& Seekins, T. (2002). Self-employment: A process for use by vocational rehabilitation agencies', Journal of Vocational Rehabilitation, 17, 107-113.

Berger, A. N., \& Udell, G. F. (2006). A more complete conceptual framework for SME finance. Journal of Banking and Finance. http://dx.doi.org/10.1016/j.jbankfin.2006.05.008

Bernard, H., Leymat, A., Kowalczuk, T., de Klerk, T., Munoz, W., du Mesnil, M., \& Bord, S. (2006). Good 
Practices for the Economic Inclusion of People with Disabilities in Developing Countries. Report for Handicap International. Retrieved from http://www.handicap-international.org/uploads/media/goodpractic es-GB-2coul.PDF

Blanck, P. D., Sandler, L. A., Schmeling, J. L., \& Schartz, H. A. (2000). Emerging workforce of entrepreneurs with disabilities: preliminary study of entrepreneurship in Iowa. Iowa Law Review, 85, 1583-1668.

Boylan, A. \& Burchardt, T. (2002). Barriers to Self-Employment for Disabled People, report for the Small Business Service. Retrieved from http://www.berr.gov.uk/files/file38357.pdf

Callahan, M., Shumpert, N., \& Mast, M. (2002). Self-employment, Choice and Self-determination. Journal of Vocational Rehabilitation, 17, 75-85.

Census of India. (2011). Office of the Registrar General and Census Commissioner India.

Davidson, J. (2011). A Qualitative Study Exploring Small Employers Recruitment Behaviour and Decisions: Small and Medium Enterprises, Department for Work and Pensions, Research Report No 754.

Dotson, W., Richman, D., Abby, L., \& Thompson, S. (2013). Teaching Skills Related to Self-employment to Adults with Developmental Disabilities: An Analog Analysis. Research in Developmental Disabilities, 34, 2336-2350.

Doyel, A. (2002). A realistic perspective of risk in self-employ employment for people with disabilities. Journal of Vocational Rehabilitation, 17, 115-24.

East Midlands Development Agency (EMDA). (2009). Scoping Study into the Business Support Needs of Disabled Entrepreneurs in the East Midlands.

Enabled4Enterprise. (2008). Barriers and Opportunities: Equipping the Enterprise Sector to Deliver Disability Smart Services. Retrieved from http://www.lcdisability.org/?lid=19899

Enabled4Enterprise. (2009). Project Report: Equipping the Enterprise Sector to deliver Disability Smart Services. Retrieved from http://www.lcdisability.org/download.php?id=1944

Foster, S. (2010). Promoting Entrepreneurship among Disabled People with Visual Impairment. Retrieved from http://www.heacademy.ac.uk/assets/documents/LLN/HWLLNPromotingentrepreneurshipvisualimpairment. pdf.

Greve, B. (2009). The Labour Market Situation of Disabled People in European Countries and Implementation of Employment Policies: A Summary of Evidence from Country Reports and Research Studies. Report prepared for the Academic Network of European Disability Experts (ANED).

Hagner, D., \& Davies, T. (2002). Doing my own thing: Supported self-employment for individuals with cognitive disabilities. Journal of Vocational Rehabilitation, 17, 65-74.

Hoang, H., \& Antoncic, B. (2003). Network-based research in entrepreneurship: A critical review. Journal of business venturing, 18(2), 165-187. http://dx.doi.org/10.1016/S0883-9026(02)00081-2

Huang, J., Guo, B., \& Bricout, J. (2009). From Concentration to Dispersion: The Shift in Policy Approach to Disability Employment in China. Journal of Disability Policy Studies, 20(1), 46-54.

Jones, M. (2008). Disability and the Labour Market: A Review of the Empirical Evidence. Journal of Economic Studies, 35(5), 405-424. http://dx.doi.org/10.1108/01443580810903554

Jones, M., \& Latreille, P. (2011). Disability and Self-employment: Evidence for the UK. Applied Economics, 43(27), 4161-4178. http://dx.doi.org/10.1080/00036846.2010.489816

Kirkwood, J. (2009). Motivational factors in a push-pull theory of entrepreneurship. Gender in Management: An International Journal, 24(5), 346-364. http://dx.doi.org/10.1108/17542410910968805

Kitching, J. (2014). Entrepreneurship and self-employment by people with disabilities. Background Paper for OECD Project on Inclusive Entrepreneurship.

Meager, N., \& Higgins, T. (2011). Disability and Skills in a Changing Economy. UK Commission for Employment and Skills. Briefing Paper Series. Retrieved from http://www.oph.fi/download/140962 equality-disability.pdf

Pagan, R. (2009). Self-employment among People with Disabilities: Evidence for Europe. Disability and Society, 24(2), 217-229. http://dx.doi.org/10.1080/09687590802652504

Prescott-Clarke, P. (1990). Employment and Handicap, No. 1036. Social and Community Planning Research, 
London.

Rizzo, D. (2002). With a little help from my friends: Supported self-employment for people with severe disabilities. Journal of Vocational Rehabilitation, 17, 97-105.

World Bank. (2013). World Development Report. Retrieved from http://www.worldbank.org/wdr2013

World Health Organisation/World Bank. (2011). World Report on Disability. Retrieved from http://www.who.int/disabilities/world_report/2011/en/index.html

\section{Copyrights}

Copyright for this article is retained by the author (s), with first publication rights granted to the journal.

This is an open-access article distributed under the terms and conditions of the Creative Commons Attribution license (http://creativecommons.org/licenses/by/3.0/). 